\title{
COMPOSITION OF GAME SITUATIONS IN THE SOLUTION HOCKEY PLAYER'S MOTORIAL TASKS
}

\author{
Vadym Kozin, Oleksandr Zykov
}

\begin{abstract}
Анотація. Розроблено підходи до застосування ситуаційної композиції в техніко-тактичній підготовці хокеїстів. Передбачено, що у процесі навчання спортсменів сприятливі ситуації повинні чергуватися 3 критичними і бути пов'язані зі специфрічним змістом. Для успішної реалізації дій необхідні знання про закономірності гри, умови конкретної ділянки ігрового поля. Ця інформація дозволить більш ефективно сприймати умови гри і формувати ситуації у свідомості гравців композиційно.

Ключові слова: модель, техніка, ситуація, діяльність, композиція.
\end{abstract}

\begin{abstract}
Аннотация. Разработаны подходы к использованию ситуационной композиции в технико-тактической подготовке хоккеистов. Предполагается, что при обучении спортсменов благоприятные ситуации должны чередоваться с критическими и иметь композиционную связь через специфическое содержание. Для успешной реализации действий, необходимы знания о закономерностях игрового процесса, условиях конкретного участка игрового поля. Данная информация позволит более эфрфективно воспринимать условия игры и формировать ситуации в сознании игроков композиционно.

Ключевые слова: модель, техника, тактика, ситуация,деятельность, композиция.
\end{abstract}

The problem of ineffective solutions hockey game tasks in conditions of interactions and counteraction caused by insufficient knowledge about the nature of the data conversion conditions. Consequently in the minds of sportsmen appear incorrect game situations and made ineffective actions leading to negative sporting performance.

It is caused as well by that in training employment the trainer operates by a principle - from quantity to quality, placing emphasis on scope and biomechanical structure of studied actions. From here players are not involved in real conditions and do not know when and how use the techniques for solving of game tasks. It conducts to that the actions finished to automatism often do not match the rules of the game and limit the range of perception of the information. The sportsman chooses the actions that he had better get on the basis of this game takes.

Introduction to sports practice the concept of «situational technique» has allowed generating the concept of impellent preparation on the basis of learning of game situations. At first, there is a training of a game situation, and then on the basis of possible conditions of this situation, there is an adaptation of studied actions [5, 6, 10].

In the subsequent, a number of authors in the works began to use widely given concept $[1,2,3$, $7,8,9]$. However, game situations in their researches are considered fragmentary, separately from each other, and it does not allow to generate a situational impellent stereotype in consciousness of the sportsman even at use of typification of situations. In works it is not specified, to what signs there is an allocation of the last, and also there is no reasoned justification.

The theme is developed according to a direction 02. «Scientific basis of elite sport (Man in the extreme conditions of motor activity)» the consolidating plan of research and development of the Ministry of sports of the Russian Federation for 20102014.

Object of research - to develop approaches to use of a situational composition in technical and tactical training of hockey players.

Methods. A systematic review of the scientific and methodological literature, synthesis of information, pedagogical observations over competitive activity of hockey players of high qualification.

Results and discussion. Game of hockey is based on the implementation of technical and tactical actions in the process of interaction and counteraction of sportsmen for the purpose of scoring. The actions made by hockey players, change conditions of game in the form of change of item position, quantitative squad of players and other characteristics with different sites of a field. In turn set of conditions on any site of a field forms a game situation. Consequently, since the throw washers into the game to stop the whistle of the referee the game situation is in a condition of constant transformation, i.e. one situation is replaced another.

The situation is considered by us from concept positions about motor situation not as a set of external circumstances, but as a scheme in the mind of the subject (person) [4]. The situation inseparably linked with the subject also cannot separately ex- 
ist. Or in other words, not external factors create a situation, and the internal relation to them. In turn the internal relation to environment is formed at the person since a birth by means of social institutes, information resources and other factors.

The situation appears as a second-order scheme. First, there is the perception of the initial conditions (simulation) of the environment, and then shaping the situation, i.e. attitudes toward the world and on the basis of this decision taken by athletes.

In our case, it looks as follows. During the game, the sportsmen perceives the conditions around them in the form teammates, opponents, positional situation between them, the number, movement speed, direction, coordination complexity, etc. Primary modeling allows the sportsmen to orient in the environment with further formation of relationships in the form of a situation. The situation for each player will be individual. Personality formation depends on the situation of gaming experience athlete's mental and physical abilities, and most importantly by learning methods.

As conditions of transformation of technical and tactical actions in the game have continuous character, and situations arising in the mind of the athlete should have a similar sequence. In addition to situations arising in the mind of the sportsmen conform to the principles, conditions, laws of the game, you need to create a knowledge of these principles, which will be based on the perceived environment (playing conditions). Or in other words, the content of knowledge possessed by the athlete in relation to the perceived information, will determine the content of a situation arising in his mind.

In training process the trainer offers separate game situations in the form of exercises, however in a series of employment relationships of cause and effect between them are not considered. That the sportsman has been involved in the real conditions, offered means should copy game situations or their separate elements. Thus situations in the form of exercises should correspond to those zones of a platform in which they are carried out more often. Moreover, the sequence of alternating funds lesson must reflect the transformation of situations in the game and have a composition.

In hockey, there are basic technical and tactical actions by which asportsman decides to emerging challenges: the actions, the pass, shot and keeping the puck. Each of these actions has ways to which the sportsman gives preferences and on their basis perceives game situations. That is tries to find those positions in which the preferred way of action could be realized.

This leads to the fact that the athlete perceives conditions through the learned methods of action to automatism. The result is that in a situation where it is necessary to carry out a goal with a comfortable hand, the athlete will ignore this situation because the mode of action does not match to which he was accustomed.

It is necessary to note, hockey contains uncountable set of game situations, studying of which all volume is not obviously possible. And studying of separate situations is insufficiently effective both for the player, and for the trainer. However, the situation repeated on the same areas of the field.

For the decision of the given problem it is offered to allocate geometrical forms of sites of a court and often arising technical and tactical actions in these areas, and also to reveal an orientation of development of game situations. And through these characteristics to reveal interconditionality between sites of a field and accordingly between game situations.

Each section of the field corresponds to the number of characteristics that are caused not only by the rules of the game, but modern trends offensive and defensive actions.

According to our observations the opportunity to enter the opponent's zone without resistance opposing team in modern hockey is very difficult, because of this game often converted into a corner site, where it is fighting for the puck and space.

In turn corners site: zone «A», characterized by the fight for the puck in close contact to the confrontation, where the number of players, as a rule, no more than 4 people. In this zone, priority is given to the ability to hold the puck in order to enter the zone $\ll B »$ and $\ll C »$ for the throwing motion (figure 1).

In training process the situation should be considered in aggregate with other situations, i.e. have a composition of different situations.

Situational composition - the process of developing situations, correlating with the result of the athlete, his activities, and regarded as an ordered parts of the game. In other words, the composition is understood as the structure of the game, fixed elements which are in close connection and interdependence.

The situational composition assumes allocation of exercises on the basis of field areas. To each field, as a rule, there corresponds a series of problems arising before the sportsman in game. Therefore and exercise without dependence from its orientation (training, perfection or development of physical qualities), should correspond first of all to specificity of a field areas and those tasks which arise in game on this position more often. The second exercise will be carried out strictly on that field weeding, in which has resulted the decision of a problem from the previous exercise. 


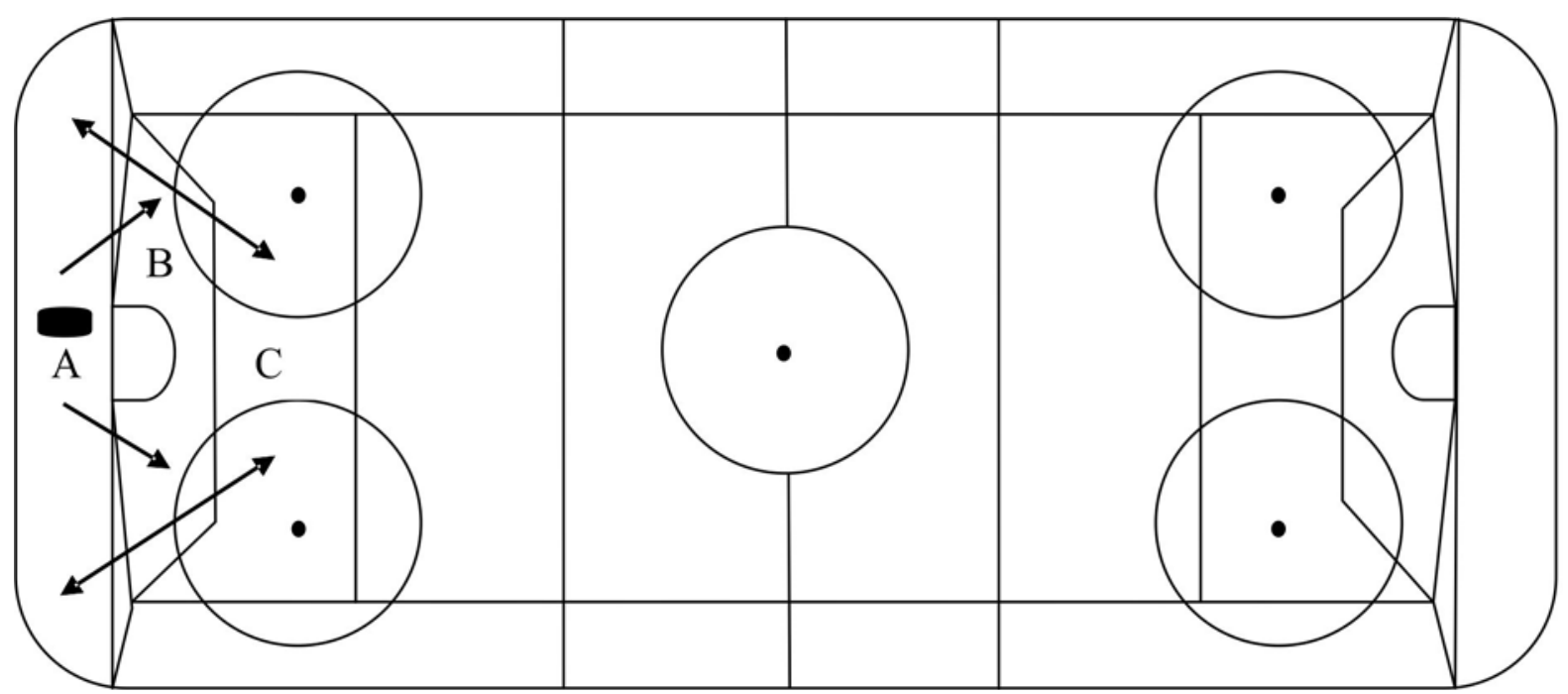

Figure 1-Allocation areas of the court based on commonly encountered situations:

A, B, C-zone

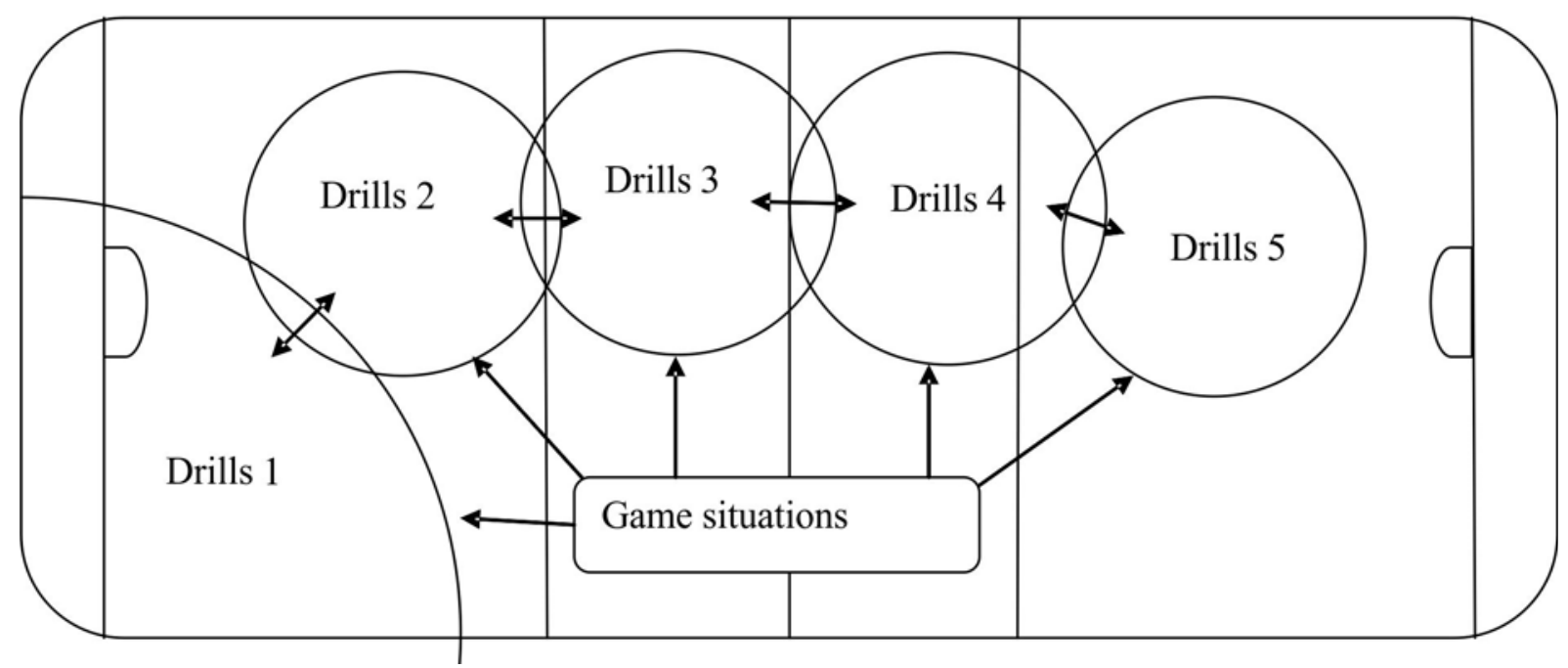

Figure 2 - One of the conversion options game situations

For example, if there is a training technical and tactical actions besides tasks directed on mastering of reception and puck passes, tasks about formation of representation of transformation of situations should be solved. That is, the basic tasks of the lesson, which focused on the implementation of technical and tactical actions in the form of sportsmen formed situational composition.

Each exercise should correspond situation in the specific area of the field, one of the solutions of the problems which converts the situation to the next position, and where should be further exercise. Each applied exercise «becomes attached» to the subsequent exercise by means of arising tasks (figure 2).

Most coaches structure the training process is to select the means of education, which is taken as a basis for quantitative composition of players, i.e. in the training beginning exercises of individual character $(1 \times 0)$ and on an accruing progression $(1 \mathrm{x} 1 ; 2 \mathrm{x} 1 ; 2 \mathrm{x} 2$ etc. $)$.

In constructing the training process should pay attention to a frequently occurring tasks in specific areas of the hockey field, then determine at what ways will their decision (considering the results of effective solutions and efficient solutions). Later in the play area, which resulted in the solution, the following exercise should be carried out, given the task and situation of the first exercise. Thus, there is continuity between the situations due to emerging challenges. In this case, the picture of the game in the minds of the sportsmen and there is integrity in competitive activity does not cause difficulties in young sportsmen.

Specificity is that this process is based on the composition. Consequently, the success of mastering 
the technical and tactical operations and the level of development of creative potential sportsmen is directly dependent on the extent to which the teaching is focused on the development of compositional skills.

At use in training of a method of a situational composition game situations and interconditionality between them are not learnt, and gradually accustom to daily training process and are steadily fixed in the form of modes in the mind of the sportsman.

At designing of a composition of situations it is necessary to choose «theme» (exit from the zone, move to the zone, a goal, etc.) to determine which proportional and logic rule are the types of situations, to identify key situations to determine their place in the composition to meet the challenges of the game episode.

For example, if the game episode begins with a face-off puck in the zone defense, then it is safe to say that the moment of the throw and it is one of the typical situations in which all begin and if the players task is a goal, then this situation will be final. Should also identify key situations, depending on the tasks and their logical relationship.
If to compare hockey with a complex system, the interaction between the players have a specific relationship to them and are in constant motion, transformed from one field to another area.

Conclusions. At training by means of a method of a situational composition, there is an alternating of situations different in the maintenance. Favorable situation (without active confrontation, low complexity of coordination, with no time limit to make a decision), alternate with critical situations in which the sportsman is in a difficult situation. This allows the player to avoid the constant expectation of a critical situation, which affects the creativity and willingness to act freely with the motor to quickly solve tasks in extreme situations.

For successful realization of actions, knowledge of laws of game process, on the conditions of a particular area of the field and frequently occurring actions on it. It will allow to compare them among themselves and to find interconditionality. This information will allow more variably perceive the playing field and create a situation in the mind of the fused composition. As a result, the internal situation of mind will coincide with the laws of the gameplay.

\section{Література}

1. Арбузин И. А. Классификация игровых ситуаций в футболе / И. А. Арбузин, В. А. Блинов // Актуальные вопросы развития детского и юношеского футбола в городе Омске: сб. ст. город. науч. практ. конфр. СибГУФК. - Омск, 2006. - С. 102-108.

2. Ахмеров В. Э. Анализ эффективности действий юных теннисистов в ситуациях разной критичности / В. Э. Ахмеров // Учен. зап. ун-та им. П. Ф. Лесгафта. - 2013. - № 3. - С. 19-25.

3. Камалов P. 3. Ситуативность - основа моделирования благоприятных ситуаций при реализации технических приемов в спортивной борьбе, и как частная теория / Р. 3. Камалов // Учен. зап. ун-та им. П. Ф. Лесгафрта. - 2013. - № 3. - С. 81-87.

4. Коренберг В. Б. Основы спортивной кинезиологии : учеб. пособие / В. Б. Коренберг. - М. : Сов. спорт, 2005. $-232 \mathrm{c}$.

5. Козин В. В. Моделирование и алгоритмизация технико-тактической деятельности спортсменов на основе ситуационной декомпозиции / В. В. Козин, Г. С. Лалаков // Физ. воспитание студ. - 2011. - № 3. C. 53-56.

6. Макаров Ю. М. Обучение ситуационной технике бросков мяча в гандболе с использованием системы развернутых алгоритмов / Ю. М. Макаров, А. А. Чуркин, А. А. Рамзайцева // Учен. зап. ун-та им. П. Ф. Лесгафрта. - 2012. - 10 (92).- С. 104-109.

7. Портных Ю. И. Дидактические основы использования игр в фризическом воспитании : автореф. дис. на соискание учен. степени д-ра пед. наук / Ю. И. Портных. - СПбГАФК им. П. Ф. Лесгафта, 1994. - 62 с.

8. Тимербаев О. М. Обучение тактическим действиям юных каратистов в спроектированных ситуациях соревновательного поединка / О. М. Тимербаев // Учен. зап. ун-та им. П. Ф. Лесгафта. - 2013. - № 1. C. $153-157$.

9. Фаттахов Р. В. Теоретические основы совершенствования методики применения игровых упражнений в обучении юных футболистов групповым тактическим действиям в нападении / Р. В. Фаттахов // Педагогико-психол. и мед.-биол. пробл. физ. культуры и спорта. - 2011. - Т. 19, № 2. - С. 91-98.

10. Яхонтов E. P. Теоретическое обоснование введения в научно-методический обиход спортивных игр понятия «ситуационная техника» / Е. Р. Яхонтов // Спортивные игры в физическом воспитании, рекреации и спорте. - Смоленск, 2006. - С. 242-254.

\section{References}

1. Arbuzin I. A. Classification of game situations in football. Aktualnye voprosy razvitiya detskogo I yunosheskogo futbola v gorode Omske: sb. st.gorodskoy nauch. prakt. konf. SibGUFK: 2006. - P. 102-108. 
2. Ahmerov V. J. Analysis of the effectiveness of young tennis players in different situations criticality. Uchenye zapiski universiteta im. P. F. Lesgafta. - 2013. - N 3. - P. 19-25.

3. Kamalov R. Z. Situational - base of modeling favorable situations when implementing techniques in wrestling, and as the special theory. Uchenye zapiski universiteta im. P. F. Lesgafta, 2013. - N 3. - P. 81-87.

4. Korenberg V. B. Fundamentals of sports kinesiology. Moscow: Sovetsky sport, 2005. - $232 \mathrm{p}$.

5. Kozin V. V. Modeling and algorithmization technical and tactical activities of athletes on the basis of situational decomposition / V. V. Kozin, G. S. Lalakov // Fizicheskoe vospitanie studentov. Nauchny zhurnal. 2011. - N 3. - P. 53-56.

6. Makarov Y. M., Churkin A. A., Ramzaitseva A. A. Education situational technique throws the ball in handball with the use of detailed algorithms. Uchenye zapiski universiteta imeni P. F. Lesgafta. 2012. - N 10 (92). P. 104-109.

7. Portnyh Y. I. Teaching the basics of using games in physical education: author's abstract for Doctoral degree in Pedagogics. Saint Petersburg SAPC P. F. Lesgaft. - 1994. - 62 p.

8. Timerbaev O. M. Education tactical actions projected to young karatekas competitive match situations. Uchenye zapiski universiteta im. P. F. Lesgafta. - 2013. - N 1. - P. 153-157.

9. Fattahov R. V. Theoretical foundations to improve methods of application of game exercises in the training of young players group tactical actions in the attack. Pedagogiko-psihologicheskie i mediko-biologicheskie problem fizicheskoy kultury I sporta. - 2011. - V. 19. - N 2. - P. 91-98.

10. Yahontov E. R. The theoretical justification for the introduction of scientific and methodological usage of sports concept «situational technique». Sportivnye igry v fizicheskom vospitanii, rekreacii i sporte, Smolensk 2006. - P. 242-254.

Сибірський державний університет фізичної культури і спорту, Омськ cousi@mail.ru

Надійшла 12.05.2014

zikou@mail.ru 